\title{
Seizure in patients with COVID-19
}

\section{Amir Emami ${ }^{1}$ - Nima Fadakar ${ }^{2} \cdot$ Ali Akbari $^{3} \cdot$ Mehrzad Lotfi $^{4} \cdot$ Mohsen Farazdaghi $^{2} \cdot$ Fatemeh Javanmardi $^{1}$. Tahereh Rezaei $^{5}$ - Ali A. Asadi-Pooya ${ }^{2,6}$ (D)}

Received: 29 June 2020 / Accepted: 15 September 2020 / Published online: 19 September 2020

(C) Fondazione Società Italiana di Neurologia 2020

\begin{abstract}
Objective The purpose of the current study was to collect the data on the occurrence of seizures in patients with COVID-19 and to clarify the circumstances of the occurrence of seizures in these patients.

Methods All consecutive patients who referred to healthcare facilities anywhere in Fars province (located in South Iran with a population of 4.851 million people) from February 19 until June 2, 2020, and had confirmed COVID-19 by positive result on polymerase chain reaction testing and seizure were included.

Results During the study period, 6,147 people had confirmed COVID-19 in Fars province, Iran; 110 people died from the illness (case fatality rate $1.79 \%$ ). During this time period, five people had seizures (seizure rate $0.08 \%$ ). In four patients, seizure was one of the presenting manifestations, and in one person, it happened during the course of hospital admission. Two patients had status epilepticus. All patients experienced hypoxemia and four of them needed respirator. Two patients had related metabolic derangements and one had cerebrospinal fluid (CSF) lymphocytic pleocytosis. Brain imaging was abnormal in three patients. Four patients died.

Conclusion New-onset seizures in critically ill patients with COVID-19 should be considered as acute symptomatic seizures and the treating physician should try to determine the etiology of the seizure and manage the cause immediately and appropriately. Detailed clinical, neurological, imaging, and electrophysiological investigations and attempts to isolate SARS-CoV-2 from CSF may clarify the role played by this virus in causing seizures in these patients.
\end{abstract}

Keywords Coronavirus · COVID · Epilepsy · Seizure

Electronic supplementary material The online version of this article (https://doi.org/10.1007/s10072-020-04731-9) contains supplementary material, which is available to authorized users.

Ali A. Asadi-Pooya

aliasadipooya@yahoo.com

Amir Emami

Emami.microbia@gmail.com

Nima Fadakar

drfanima@gmail.com

Ali Akbari

aeshahin2002@yahoo.com

Mehrzad Lotfi

lotfimz@yahoo.com

Mohsen Farazdaghi

m_farazdaghi@yahoo.com

Fatemeh Javanmardi

javanmardi.biostat@yahoo.com
Tahereh Rezaei

tahererezaei84@gmail.com

1 Burn \& Wound Healing Research Center, Shiraz University of Medical Sciences, Shiraz, Iran

2 Epilepsy Research Center, Shiraz University of Medical Sciences, Shiraz, Iran

3 Department of Anesthesiology, School of Medicine, Shiraz University of Medical Sciences, Shiraz, Iran

4 Medical Imaging Research Center, Shiraz University of Medical Sciences, Shiraz, Iran

5 Non-Communicable Diseases Research Center, Shiraz University of Medical Sciences, Shiraz, Iran

6 Jefferson Comprehensive Epilepsy Center, Department of Neurology, Thomas Jefferson University, Philadelphia, PA, USA 


\section{Introduction}

Since the beginning of the year 2020, the world has been experiencing a catastrophic pandemic of coronavirus disease (COVID-19) that is caused by SARS-CoV-2 [1]. As this is a newly emerged viral infection, we have been learning a lot about the presentations of COVID-19 with the passage of time [2]. While seizures had not been widely reported in the first few months of COVID-19 pandemic [3-5], there has been increasing numbers of reports of seizures in patients with COVID-19 recently [6-8]. Patients with COVID-19 may have hypoxia, multiorgan failure, and severe metabolic and electrolyte disarrangements [9]; therefore, it is plausible to expect acute symptomatic seizures to occur in these patients. Furthermore, a growing body of evidence indicates that neurotropism is one common feature of coronaviruses [10, 11]. Seizures had been reported in outbreaks of coronavirus infections (severe acute respiratory syndrome (SARS) in 2002 and the Middle East respiratory syndrome (MERS) in 2012) before [12-14].

The purpose of the current study was to collect the data on the occurrence of seizures in patients with COVID-19 and to clarify the circumstances of the occurrence of seizures in people who are infected with this virus.

\section{Methods}

Iran reported its first confirmed cases of SARS-CoV-2 infection on 19 February 2020. As of 24 June 2020, there have been 9,863 COVID-19 deaths with 209,970 confirmed infections in Iran [15]. In this study, all consecutive patients who referred to healthcare facilities anywhere in Fars province (located in South Iran with a population of 4.851 million people) from February 19 until June 2, 2020, and had confirmed COVID-19 by positive result on real-time polymerase chain reaction (qRT-PCR) testing of nasopharyngeal and oropharyngeal (NP/OP swabs) samples, which were inserted in the same tube, were included. The denominator was the total number of the people with confirmed COVID-19 in Fars province during that time period. The numerator was the number of people with seizures. The clinical manifestations and paraclinical findings of patients with seizure were collected retrospectively and after reviewing their medical records.

\section{Standard protocol approvals, registrations, and patient consents}

Shiraz University of Medical Sciences Review Board approved this study as a minimal-risk research using the data that were collected for routine clinical practice and waived the requirement for informed consent. Information was collected and entered into the electronic registry of Shiraz University of Medical Sciences (Ethics code: IR.SUMS.REC.1399.022).

\section{Results}

From February 19 until June 2, 2020, 6,147 people had confirmed COVID-19 in Fars province, Iran; 110 people died from the illness (case fatality rate $1.79 \%$ ). During this time period, five people had tonic-clonic seizures (seizure rate $0.08 \%$ ). In four patients, seizure was one of the presenting manifestations, and in one person, it happened during the course of the hospital admission. Table 1 describes demographics and clinical manifestations of the patients with COVID-19 and seizures. Adults and children, women, and men with COVID-19 had seizures in our series. Two patients had additional neurological manifestations, other than seizure and altered mental status (Table 1). While two patients had comorbid human immune deficiency virus (HIV) infection, none had pre-existing epilepsy. Two patients had status epilepticus (one adult person with comorbid HIV infection and one child with febrile status epilepticus). All patients experienced hypoxemia and four of them needed ventilators. Two patients had related (to seizures) metabolic derangements (increased BUN and creatinine in one (BUN $49 \mathrm{mg} / \mathrm{dL}$, creatinine $2.8 \mathrm{mg} / \mathrm{dL}$ ) and hyponatremia (blood sodium level $=126$ $\mathrm{mEq} / \mathrm{L}$ ) in another). Lumbar puncture was performed in two patients; one had lymphocytic pleocytosis and one had normal results; PCR test on cerebrospinal fluid (CSF) for SARS$\mathrm{CoV}-2$ was not done in any patient. Brain imaging was done in four patients; three had abnormal findings (see Table 1). Electroencephalography was performed in two patients; both had diffuse slowing. Two patients received hydroxychloroquine and three people did not. Four patients died and one child was discharged in a healthy condition with no further seizures.

\section{Discussion}

In this study, we observed that seizure could be seen in both sexes and all ages and patients with COVID-19 may have de novo seizures without a history of epilepsy. Patients with COVID-19 may develop seizures as a consequence of hypoxia, metabolic derangements, organ failure, or even neuroinvasion or cerebral damage that may happen in these patients [9]. The specific SARS-CoV-2 RNA was detected in the CSF in a patient with meningoencephalitis in a previous study [4]. While one of our patients had CSF lymphocytic pleocytosis, we cannot confirm a COVID-related meningoencephalitis (we did not have PCR test on the CSF for SARSCoV-2). 
Table 1 Characteristics of patients with COVID-19 and seizure

\begin{tabular}{|c|c|c|c|c|c|}
\hline & Patient \# 1 & Patient \# 2 & Patient \# 3 & Patient \# 4 & Patient \# 5 \\
\hline Age & 54 years & 42 years & 35 years & 2.9 years & 2 days (term) \\
\hline Sex & Female & Male & Male & Male & Female \\
\hline Chief complaint & $\begin{array}{c}\text { Seizure (status } \\
\text { epilepticus) }\end{array}$ & Fever, cough & Altered mental status & Fever, status epilepticus & Respiratory distress \\
\hline $\begin{array}{l}\text { Time of seizure } \\
\text { from the } \\
\text { onset }\end{array}$ & 1 st day & 15 th day & 1st day & 1st day & 1st day \\
\hline Fever & No & Yes & Yes & Yes & No \\
\hline Cough & Yes & Yes & Yes & No & No \\
\hline $\begin{array}{l}\text { Respiratory } \\
\text { distress }\end{array}$ & Yes & Yes & Yes & No & Yes \\
\hline Headache & No & No & No & - & - \\
\hline $\begin{array}{l}\text { Altered mental } \\
\text { status }\end{array}$ & Yes & No & Yes & Yes & Yes \\
\hline $\begin{array}{l}\text { Other } \\
\text { neurological } \\
\text { symptoms/- } \\
\text { signs }\end{array}$ & No & No & $\begin{array}{l}\text { Left pupil } 2 \mathrm{~mm} \\
\text { non-reactive (right } 3 \mathrm{~mm} \\
\text { reactive) }\end{array}$ & $\begin{array}{l}\text { Dysarthria, bilateral upward } \\
\text { plantar reflexes }\end{array}$ & No \\
\hline $\begin{array}{l}\text { Other } \\
\text { signs/- } \\
\text { symptoms }\end{array}$ & No & No & $\begin{array}{l}\text { Increased secretions, } \\
\text { bilateral rales }\end{array}$ & $\begin{array}{l}\text { Nausea, vomiting, } \\
\text { abdominal pain }\end{array}$ & No \\
\hline Comorbidity & HIV infection & No & HIV infection & Allergy to cow milk & Low birth weight \\
\hline $\mathrm{PaO} 2$ & $68-90$ & $22-88$ & $58-100$ & $52-91$ & 37 \\
\hline Admitted & ICU & ICU & ICU & ICU & ICU \\
\hline Ventilator & Yes & No & Yes & Yes & Yes \\
\hline $\begin{array}{l}\text { Abnormal } \\
\text { blood works }\end{array}$ & $\begin{array}{l}\text { BUN } 49 \mathrm{mg} / \mathrm{dL}, \\
\text { creatinine } 2.8 \\
\text { mg/dL, platelet } \\
55,000 \text { per } \\
\text { microliter }\end{array}$ & $\begin{array}{l}\text { D-Dimer } 6396 \text { ng/mL, } \\
\text { PTT } 56 \text { s, LDH } 1398 \\
\text { U/L }\end{array}$ & $\begin{array}{l}\mathrm{CRP} 91 \mathrm{mg} / \mathrm{L}, \text { ESR } 98 \\
\mathrm{~mm} / \mathrm{h}\end{array}$ & $\begin{array}{l}\text { Troponin I } 154 \text { ng/ml, CPK } \\
482 \text { U/L, CRP } 105 \text { mg/L, } \\
\text { LDH1019 U/L }\end{array}$ & $\begin{array}{l}\text { Total bilirubin } 6 \\
\text { mg/dL, bicytopenia } \\
\text { (RBC } 1.93 \times 10^{6} \\
\text { and WBC } 2000 \text { per } \\
\text { microliter), blood } \\
\text { sodium level = } 126 \\
\text { mEq/L }\end{array}$ \\
\hline CSF & $\begin{array}{l}6 \mathrm{PMN}, 14 \\
\text { lymphocytes, } \\
\text { normal protein } \\
\text { and glucose }\end{array}$ & Not done & Not done & $\begin{array}{l}\text { 1st: } 1 \text { PMN, normal protein } \\
\text { and glucose } 2 \text { nd: No cell, } \\
\text { normal protein and } \\
\text { glucose }\end{array}$ & Not done \\
\hline Chest X-ray & $\begin{array}{l}\text { Bilateral diffuse } \\
\text { infiltration }\end{array}$ & Not done & Not done & Bilateral diffuse infiltration & $\begin{array}{l}\text { Bilateral diffuse } \\
\text { infiltration }\end{array}$ \\
\hline Chest CT scan & $\begin{array}{l}\text { Bilateral diffuse } \\
\text { infiltration }\end{array}$ & $\begin{array}{l}\text { Bilateral ground-glass } \\
\text { opacity }\end{array}$ & $\begin{array}{l}\text { Multiple nodule and cavity } \\
\text { in favor of septic emboli }\end{array}$ & Not done & Not done \\
\hline Brain imaging & $\begin{array}{l}\text { Brain CT: Basal } \\
\text { frontal } \\
\text { hypodensity }\end{array}$ & Not done & $\begin{array}{l}\text { Brain CT: right ischemic } \\
\text { stroke }\end{array}$ & $\begin{array}{l}\text { Brain CT: Right occipital } \\
\text { mass and intracerebral } \\
\text { hemorrhage. Brain MRI: } \\
\text { Right occipital mass } \\
\text { (ganglioglioma?)+ } \\
\text { intracerebral hemorrhage } \\
\text { intracerebral } \\
\text { hemorrhage }^{9}\end{array}$ & $\begin{array}{l}\text { Brain sonography: } \\
\text { Normal }\end{array}$ \\
\hline EEG & $\begin{array}{l}\text { Generalized } \\
\text { slowing }\end{array}$ & Not done & Not done & Generalized slowing & Not done \\
\hline $\begin{array}{l}\text { Treatment } \\
\text { (ASM) }\end{array}$ & $\begin{array}{l}\text { Levetiracetam, } \\
\text { midazolam }\end{array}$ & Midazolam & $\begin{array}{l}\text { Midazolam, fentanyl, } \\
\text { levetiracetam }\end{array}$ & $\begin{array}{l}\text { Phenobarbital, } \\
\text { levetiracetam, valproate, } \\
\text { phenytoin, midazolam, } \\
\text { thiopental, fentanyl }\end{array}$ & Phenobarbital \\
\hline $\begin{array}{l}\text { Other } \\
\text { medications }\end{array}$ & $\begin{array}{l}\text { Famotidine, } \\
\text { ciprofloxacin, } \\
\text { clindamycin, } \\
\text { heparin, } \\
\text { pantoprazol, }\end{array}$ & $\begin{array}{l}\text { Ranitidine, ondansetron, } \\
\text { oseltamivir, } \\
\text { levofloxacin, } \\
\text { vancomycin, } \\
\text { lopinavir/ritonavir, }\end{array}$ & $\begin{array}{l}\text { Dexamethasone, } \\
\text { vancomycin, atorvastatin, } \\
\text { morphine, acetazolamide, } \\
\text { dextromethorphan, } \\
\text { acetaminophen, }\end{array}$ & $\begin{array}{l}\text { Colistin, pantoprazole, } \\
\text { acetaminophen, } \\
\text { meropenem, } \\
\text { hydroxychloroquine, } \\
\text { vancomycin, }\end{array}$ & $\begin{array}{l}\text { Ampicillin, amikacin, } \\
\text { vitamin } \mathrm{K}, \\
\text { ceftrixone, } \\
\text { pantoprazole }\end{array}$ \\
\hline
\end{tabular}


Table 1 (continued)

\begin{tabular}{|c|c|c|c|c|c|}
\hline & Patient \# 1 & Patient \# 2 & Patient \# 3 & Patient \# 4 & Patient \# 5 \\
\hline & $\begin{array}{l}\text { propranolol, } \\
\text { acyclovir, } \\
\text { etomidate }\end{array}$ & $\begin{array}{l}\text { hydroxychloroquine, } \\
\text { ribavirin, meropenem, } \\
\text { vancomycin, } \\
\text { ipratropium, salbutamol, } \\
\text { salmeterol/fluticasone }\end{array}$ & $\begin{array}{l}\text { meropenem, } \\
\text { N-acetylcysteine, } \\
\text { magnesium hydroxide, } \\
\text { amikacin, enoxaparin, } \\
\text { clonidine, } \\
\text { lopinavir/ritonavir }\end{array}$ & $\begin{array}{l}\text { domperidone, acyclovir, } \\
\text { dexamethasone, } \\
\text { N-acetylcysteine, } \\
\text { enoxaparin, vitamin } \\
\text { B-complex, } \\
\text { norepinephrine, } \\
\text { furosemide, potassium } \\
\text { chloride, packed cell }\end{array}$ & \\
\hline Outcome & Expired in ICU & Expired in ICU & Expired in ICU & Discharged & Expired in ICU \\
\hline $\begin{array}{l}\text { Duration of } \\
\text { admission } \\
\text { (days) }\end{array}$ & 7 & 3 & 31 & 21 & 3 \\
\hline Follow-up & - & - & - & $\begin{array}{l}4 \text { days after being } \\
\text { discharged: No problem, } \\
\text { no seizures }\end{array}$ & - \\
\hline
\end{tabular}

$H I V$ human immune deficiency virus, $I C U$ intensive care unit, $B U N$ blood urea nitrogen, $P T T$ partial thrombin time, $L D H$ lactate dehydrogenase, $C R P C$ reactive protein, $E S R$ erythrocyte sedimentation rate, $C P K$ creatine phosphokinase, $P R L$ prolactin, $R B C$ red blood cell, $W B C$ white blood cell, $P M N$ polymorphonuclear leukocytes

@ pathology: normal brain tissue with dilated vessels and hemorrhage

Cerebrovascular events have been reported in patients with COVID-19 in multiple studies $[2,16]$. Two of our patients had such findings in their brain imaging studies. There is a case with COVID-19-associated encephalitis mimicking a glial tumor in the literature [17]. One of our patients had a similar finding in his brain imaging/pathology studies. Other scenarios for acute symptomatic seizures in critically ill patients with COVID-19 have also been reported before [18-21]. All of our patients were admitted to intensive care unit (ICU) and had hypoxemia, two patients had metabolic derangements, and one child suffered from febrile status epilepticus.

Unfortunately, four of our patients died at the hospital. While total case fatality rate was $1.79 \%$, this rate of $80 \%$ mortality among patients with seizures seems to be very high. However, we cannot establish a cause and effect relationship between seizure and mortality in patients with COVID-19 based on this study, because of the small number of patients with seizures.

While the rate of convulsive seizures was small in our study and most previous studies [2-6], in previous studies, change in mental status have been reported in about $10 \%$ of patients with severe COVID-19 [2]. However, EEG has not been done in most previous studies to investigate the possibility of non-convulsive status epilepticus (NCSE) in patients with altered responsiveness and COVID-19. One small study of 22 patients with confirmed COVID-19 showed that the most common indications for EEG were new-onset encephalopathy and seizure-like events. Sporadic epileptiform discharges were present in $41 \%$ of the patients [8]. It is recommended to perform a continuous EEG monitoring in a patient who is in a critical medical condition, including those with
COVID-19, and has a change in mental status to make sure that NCSE is not a part of the clinical scenario [9].

New-onset seizures in critically ill patients with COVID-19 should be considered as acute symptomatic seizures, and therefore, long-term antiseizure medication (ASM) therapy is often not needed, unless a subsequent seizure happens [9]. However, the treating physician should try to determine the etiology of the seizure and manage the cause immediately and appropriately. Detailed clinical, neurological, imaging, and electrophysiological investigations and attempts to isolate SARS-CoV-2 from CSF may clarify the role played by this virus in causing seizures in these patients.

\section{Limitations}

This study was cross-sectional in design and the data were collected retrospectively. Furthermore, we did not have access to the whole database and information on all 6,147 patients to compare these patients with those without seizures. This study should be replicated in other populations. Finally, in most patients, EEG and CSF analyses were not done and PCR test on the CSF for SARS-CoV-2 was not done in any patient.

Authors' contributions Ali A. Asadi-Pooya, M.D.: Design and conceptualized the study, analyzed the data, and drafted and revised the manuscript. Others: Data collection and revision of the manuscript.

Funding Shiraz University and Shiraz University of Medical Sciences financially supported this study. Shiraz University and Shiraz University of Medical Sciences had no role in the study design; in the collection, analysis, and interpretation of data; in the writing of the report; and in the decision to submit the paper for publication. 
Data availability The data use in this study is confidential and will not be shared.

\section{Compliance with ethical standards}

Shiraz University of Medical Sciences Review Board approved this study.Conflict of interest Ali A. Asadi-Pooya, M.D.: Honoraria from Cobel Daruo, RaymandRad, Sanofi, and Tekaje; Royalty: Oxford University Press (Book publication). Others: none.

\section{References}

1. Rothan HA, Byrareddy SN (2020) The epidemiology and pathogenesis of coronavirus disease (COVID-19) outbreak. J Autoimmun 109:102433

2. Asadi-Pooya AA, Simani L (2020) Central nervous system manifestations of COVID-19: a systematic review. J Neurol Sci 413: 116832

3. Mao L, Wang M, Chen S et al (2020) Neurological manifestations of hospitalized patients with COVID-19 in Wuhan, China: a retrospective case series study. JAMA Neurol:e201127

4. Moriguchi T, Harii N, Goto J, Harada D, Sugawara H, Takamino J, Ueno M, Sakata H, Kondo K, Myose N, Nakao A, Takeda M, Haro H, Inoue O, Suzuki-Inoue K, Kubokawa K, Ogihara S, Sasaki T, Kinouchi H, Kojin H, Ito M, Onishi H, Shimizu T, Sasaki Y, Enomoto N, Ishihara H, Furuya S, Yamamoto T, Shimada S (2020) A first case of meningitis/encephalitis associated with SARS-Coronavirus-2. Int J Infect Dis 94:55-58

5. Lu L, Xiong W, Liu D, Liu J, Yang D, Li N, Mu J, Guo J, Li W, Wang G, Gao H, Zhang Y, Lin M, Chen L, Shen S, Zhang H, Sander JW, Luo J, Chen S, Zhou D (2020) New-onset acute symptomatic seizure and risk factors in coronavirus disease 2019: a retrospective multicenter study. Epilepsia 61:e49-e53

6. Pinna P, Grewal P, Hall JP, Tavarez T, Dafer RM, Garg R, Osteraas ND, Pellack DR, Asthana A, Fegan K, Patel V, Conners JJ, John S, Silva ID (2020) Neurological manifestations and COVID-19: experiences from a tertiary care center at the frontline. J Neurol Sci 415:116969

7. Nalleballe K, Reddy Onteddu S, Sharma R et al (2020) Spectrum of neuropsychiatric manifestations in COVID-19. Brain Behav Immun S0889-1591(20):31008-31004

8. Galanopoulou AS, Ferastraoaru V, Correa DJ, Cherian K, Duberstein S, Gursky J, Hanumanthu R, Hung C, Molinero I, Khodakivska O, Legatt AD, Patel P, Rosengard J, Rubens E, Sugrue W, Yozawitz E, Mehler MF, Ballaban-Gil K, Haut SR, Moshé SL, Boro A (2020) EEG findings in acutely ill patients investigated for SARS-CoV-2/COVID-19: a small case series preliminary report. Epilepsia Open 5:314-324

9. Asadi-Pooya AA (2020) Seizures associated with coronavirus infections. Seizure 79:49-52

10. Bohmwald K, Gálvez NMS, Ríos M, Kalergis AM (2018) Neurologic alterations due to respiratory virus infections. Front Cell Neurosci 12:386

11. Li YC, Bai WZ, Hashikawa T (2020) The neuroinvasive potential of SARS-CoV2 may be at least partially responsible for the respiratory failure of COVID-19 patients. J Med Virol 92:552-555

12. Hung EC, Chim SS, Chan PK et al (2003) Detection of SARS coronavirus RNA in the cerebrospinal fluid of a patient with severe acute respiratory syndrome. Clin Chem 49:2108-2109

13. Lau KK, Yu WC, Chu CM, Lau ST, Sheng B, Yuen KY (2004) Possible central nervous system infection by SARS coronavirus. Emerg Infect Dis 10:342-344

14. Saad M, Omrani AS, Baig K, Bahloul A, Elzein F, Matin MA, Selim MAA, Mutairi MA, Nakhli DA, Aidaroos AYA, Sherbeeni NA, al-Khashan HI, Memish ZA, Albarrak AM (2014) Clinical aspects and outcomes of 70 patients with Middle East respiratory syndrome coronavirus infection: a single-center experience in Saudi Arabia. Int J Infect Dis 29:301-306

15. https://www.coronatracker.com/country/iran/accessed on June 24, 2020.

16. Pons-Escoda A, Naval-Baudín $\mathrm{P}$, Majós $\mathrm{C}$, Camins A, Cardona $\mathrm{P}$, Cos M, Calvo N (2020) Neurologic involvement in COVID-19: cause or coincidence? A neuroimaging perspective. AJNR Am J Neuroradiol 41:1365-1369

17. Efe IE, Aydin OU, Alabulut A, Celik O, Aydin K (2020) COVID19-associated encephalitis mimicking glial tumor. World Neurosurg 140:46-48

18. Hepburn M, Mullaguri N, George P et al (2020) Acute symptomatic seizures in critically ill patients with COVID-19. Neurocrit Care:15. https://doi.org/10.1007/s12028-020-01006-1 Online ahead of print

19. Niazkar HR, Zibaee B, Nasimi A, Bahri N (2020) The neurological manifestations of COVID-19: a review article. Neurol Sci 41:16671671

20. Asadi-Pooya AA, Attar A, Moghadami M, Karimzadeh I (2020) Management of COVID-19 in people with epilepsy: drug considerations. Neurol Sci 41:2005-2011

21. Iroegbu JD, Ifenatuoha CW, Ijomone OM (2020) Potential neurological impact of coronaviruses: implications for the novel SARSCoV-2. Neurol Sci 41:1329-1337

Publisher's note Springer Nature remains neutral with regard to jurisdictional claims in published maps and institutional affiliations. 